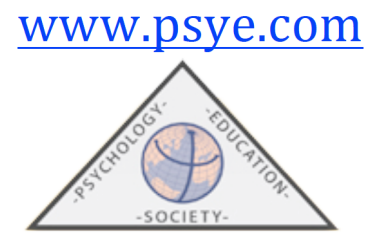

\title{
Teacher Professional Development: International Perspectives and Approaches
}

\author{
Alfredo BAUTISTA* \& Rosario ORTEGA-RUIZ** \\ (*) Nanyang Technological University, National Institute of Education (Singapore) \\ $(* *)$ University of Córdoba, Department of Psychology (Spain)
}

\begin{abstract}
Nations around the world are currently embarked in deep reforms of their education systems. There is widespread agreement among policymakers, scholars, and educators that one of the keys for success during these reforms is promoting the professional development (PD) of in-service teachers. Every year, governments invest astronomical amounts of money on teacher continuous learning. However, the literature shows that much of the PD offered to teachers is inefficient, having small or no effect on teaching practices and/or student learning. This monograph describes the perspectives and approaches to teacher PD of five nations heavily committed to research and/or practice in this field. Understanding how PD is structured in these nations may guide others in designing more favorable learning opportunities for their teachers. The article from United States provides a general framework regarding the features of high-quality PD and offers examples of recent effective initiatives. The four following articles describe the PD models of Australia, Hong Kong, Finland, and Singapore, among the highest-achievers in education presently. Because teacher continuous learning is a high priority in these nations, strong infrastructures for high-quality PD have been built to meet teachers' needs and interests. The monograph closes with a contribution from Spain, the country where the journal Psychology, Society and Education is edited. The author discusses the five prior articles and reflects on how the ideas presented could improve the PD currently offered to teachers in other nations, particularly Spain.
\end{abstract}

Keywords: professional development, in-service teachers, education change, comparative education

Correspondence: Alfredo Bautista, Research Scientist \& Lecturer. Nanyang Technological University - National Institute of Education. Education \& Cognitive Development Lab. 1 Nanyang Walk. NIE5-B3-16. Singapore [637616]. Phone: (+65) 6219 6256. Fax: (+65) 6896 9845. E-mail: Alfredo.Bautista@nie.edu.sg

\section{How to cite this article?}

Bautista, A., \& Ortega-Ruíz, R. (2015). Teacher professional development: International perspectives and approaches. Psychology, Society and Education, 7(3), 240-251. 


\section{Introduction}

We live in an increasingly globalized world, where countries are subject to massive economic, political, and technological changes. Education is also undergoing rapid transformations under the effects of globalization. However, despite its importance in shaping our future, education is not always analyzed according to the parameters that have yielded high quality results in certain educational systems. Local policies still prevail over scientific knowledge in determining the direction of most nations with regards to education. This monograph draws on the idea that making explicit the parameters that define high-quality education is essential in today's globalized world. In particular, the present monograph focuses on how to best promote and facilitate the professional development (PD) of teachers in the $21^{\text {st }}$ century.

Teacher PD involves many processes, actions, and mechanisms which are inevitably mediated by the cultural, social, political, and economic features and conditions of each particular context (Tan \& Dimmock, 2014). In the frame of a complex (situational, contextual, ecological) theoretical perspective (Opfer \& Peder, 2011), our interest in this monograph is to showcase the perspectives and approaches to teacher PD of certain nations heavily committed to research and/or practice in this field. Some of the questions that motivated this monograph were: What models are adopted in countries that have developed highly effective and/or innovative PD initiatives over the past years? What are the similarities in the ways teachers engage in PD activities in these countries? What are the differences? What kinds of challenges do these nations face? How do cultural, social, political, and economic factors shape PD practices across the globe? We thought that exploring these topics was a worthwhile effort, with the potential to enrich our understanding of the mechanisms that underlie teacher learning in our current globalized world.

\section{Teachers in an Era of Educational Reforms}

Nations around the world are currently embarked in deep reforms of their education systems. One of the most substantial changes introduced relates to the dramatic transformation in the types and nature of learning outcomes expected from students. Ambitious learning goals, including both academic and non-academic outcomes, have been set in many countries (Todd, 2010).

The purpose of today's school is not simply to deliver subject matter knowledge (mathematics, science, language, etc.) and prepare students for their future professional careers. The purpose is rather to educate $21^{\text {st }}$ century citizens: active, self-directed, confident and concerned learners, competent not only cognitively but also emotionally, socially, and technologically. It is also important to educate students who are able to make responsible decisions, equipping them with the so-called $21^{\text {st }}$ century competences and skills (able to think critically and creatively, to communicate and collaborate with others effectively, aware of global and cross-cultural issues, etc.) (Burnaford, Brown, Doherty, \& McLaughlin, 2007). Another important change introduced by reforms in many nations has to do with the goal of promoting equity and social justice in schools (e.g., Apple, 2001). The expectation is for schools to work equitably and effectively for all learners in ever 
more diverse classrooms, hence contributing to a better, more just and free society (Kaur, 2012).

Changes of this magnitude necessarily require profound transformations in curriculum and instructional practices, in what and how teachers teach to students (Bautista, Tan, Ponnusamy, \& Yau, 2015). Indeed, teachers are key to the success of reform initiatives, as they are ultimately the ones in charge of enacting these initiatives within the classroom (Guskey, 2002). In the $21^{\text {st }}$ century, teachers are expected to play a variety of roles in schools. Fulfilling these roles requires a wide range of professional and personal competencies (Darling-Hammond, Chung Wei, Andree, Richardson, \& Orphanos, 2009). Teachers need to be able to provide all students with opportunities for deep and meaningful learning, thereby fostering their holistic development. Being a teacher also requires being able to work collaboratively with others (including colleagues and parents), seeking out opportunities for further learning within and beyond the school. Furthermore, teachers need to possess certain personal values that allow them to act as leaders of social change. They need to be able to maintain high-quality content instruction while adopting a social justice orientation, helping students to recognize and undermine patterns of injustice and oppression. In a nutshell, teachers need to believe that every single student can learn (Darling-Hammond et al., 2009). Ensuring that teachers are appropriately equipped with this sophisticated array of competencies (e.g., knowledge and skills related to professional practice, collaboration and leadership, integrity and commitment to education and social change, etc.) is therefore essential to guarantee the success of educational reforms (Garet, Porter, Desimone, Birman, \& Kwang, 2001). However, research has shown that many teachers need intensive guidance and support to be able to teach according to innovative principles (Borko, 2004). In fact, scholars have argued that many prior initiatives for educational improvement have not accomplished the intended goals because they failed to provide teachers with appropriate learning opportunities (Fullan \& Miles, 1992).

There is widespread agreement among policymakers, scholars, and educators that promoting the professional development (PD) of in-service teachers is a cornerstone to achieve the ambitious goals of educational reforms (Desimone, Porter, Garet, Yoon, \& Birman, 2002). Indeed, there is currently general consensus that the quality of an education system cannot be higher than the quality of its teachers (Barber \& Mourshed, 2007). For this reason, many nations across the world are investing in the continuous learning of their teachers as a major engine for the improvement of both teacher competency and student academic success (DarlingHammond, Chung Wei, \& Andree, 2010). As pointed out by Knight (2002), providing teachers with opportunities for PD is essential because initial teacher education programs cannot provide them with all the competencies that are needed in the classroom, especially the procedural ("how to") skills, which primarily develop in practical settings. The expectation for today's teachers is to embrace life-long learning to be able to constantly adapt to new situations and respond to the changing demands of society in the classroom. Moreover, providing teachers with PD opportunities commonly improves their job commitment and satisfaction, hence 
having positive effects over attrition and turnover (Dede, Ketelhut, Whitehouse, Breit, \& McCloskey, 2009).

\section{Defining Teacher Professional Development (PD)}

The literature presents multiple conceptualizations regarding the scope, focus, and goals of teacher professional development (PD). One of the aspects where there is no full consensus is the target audience of PD. Most authors within the anglosaxon research community argue that PD is all about in-service teachers, as only these can be truly regarded as professionals (Little, 1993). In this perspective, teacher PD is seen as equivalent to in-service teacher education (continuing, ongoing). In contrast, other authors understand that teacher education programs are part of teachers' professional journey, therefore arguing that student teachers (pre-service) can be also considered as the target audience of teacher PD activities (Niemi, 2015). This monograph includes articles based on both perspectives.

With regards to the focus and main goals of PD, authors such as Borko (2004) and Desimone et al. (2002) conceive teacher PD to be an essential mechanism for enhancing teachers' knowledge and instructional practices. Bringing about changes in teachers' attitudes and beliefs is, for authors like Guskey (2002), another major objective of PD. More recently, authors such as Kazemi and Hubbard (2008) and Opfer and Peder (2011) have emphasized the need for more complex understandings, arguing that PD has the potential to impact many aspects of teachers' professional and personal lives, impacting on teachers' knowledge, competences, and values. In this monograph, we subscribe to the definition proposed by Avalos (2011), as it nicely articulates a number of relevant topics that have been discussed in recent years by researchers in the field. As captured in Avalos' definition, we consider that the focus and ultimate goal of teacher PD should be the benefit of students' learning and achievement.

"[...] professional development is about teachers learning, learning how to learn, and transforming their knowledge into practice for the benefit of their students' growth. Teacher professional learning is a complex process, which requires cognitive and emotional involvement of teachers individually and collectively, the capacity and willingness to examine where each one stands in terms of convictions and beliefs and the perusal and enactment of appropriate alternatives for improvement or change." (Avalos, 2010; p.10)

The field of teacher PD constitutes a domain of research in its own right, with its own set of theories and models (Avalos, 2011). During its three decades of life, researchers have proposed multiple theoretical perspectives on how teachers learn and change. These range from unidirectional (Guskey, 2002) and multidirectional models (Desimone, 2009), in which teacher learning is conceived of as a rather direct consequence of certain processes and conditions, to models based on complexity theories (Opfer \& Peder, 2011), in which teacher learning is conceptualized as a rather unpredictable outcome of cyclical and dynamic processes.

The literature contains many types of studies, from small to large-scale, 
including quantitative, mixed-methods, and qualitative designs. Program evaluations are probably the most common study type. In these, researchers have looked at the impact of specific PD programs on teachers (e.g., whether and how PD fostered changes in their beliefs, content knowledge, or pedagogies) and/or students (e.g., whether and how PD was associated to gains in learning, or better performance in standardized tests). In addition, there have been many survey studies about teachers' prior PD experiences, in-depth analysis of successful PD practices, and more recently, experimental studies (e.g., cluster randomized trials) (for a synthesis of the literature, see Avalos, 2011).

\section{On the Effectiveness of Teacher PD}

The field of teacher PD has accumulated solid knowledge of what works on the ground and what doesn't when it comes to promoting teacher learning. Most research has yielded disappointing results with regards to the effectiveness of PD in helping teachers improve their knowledge and instructional practices (e.g., Garet et al., 2008; Garet et al., 2011; O’Dwyer et al., 2010; Powell, Diamond, Burchinal, \& Koehler, 2010). Results are even more disappointing regarding impact on student learning and achievement (e.g., Garet et al., 2008, 2011; O’Dwyer et al., 2010; Powell et al., 2010). Every year, governments around the world invest astronomical amounts of money on traditional PD activities such as seminars, talks, workshops, and conferences (Gersten, Dimino, Jayanthi, Kim, \& Santoro, 2010; Yoon, Duncan, Lee, Scarloss, \& Shapley, 2007), brief and sporadic events in which teachers tend to be passive recipients of information, having no opportunities to collaborate with others. Ball (1995) has referred to these activities as "style shows," and Darling-Hammond (2010) as the "spray and pray approach" given the lack of structures to provide teachers with feedback and follow-up support. Scholars such as Borko (2004) argue that these types of PD are "woefully inadequate" because they tend to be fragmented and intellectually superficial, disconnected from classroom practices, and unrelated to teachers' actual needs and interests.

These PD activities generally arise from local developers (who are oftentimes not well-equipped with relevant knowledge on PD theory and practice), and have a relatively short life and scope. In addition, they generally proceed with no more formal evaluation than satisfaction surveys upon course completion (DarlingHammond, 2010). We know today that these traditional PD activities have very limited or null potential to improve teachers "value added" scores, and therefore no potential to benefit students (Hill, Beisiegel, \& Jacob, 2013). However, perhaps due to lack of better alternatives or ideas (Little, 1993), many schools and school districts around the world continue to invest their resources in organizing these kinds of PD events -conducting one-off workshops, inviting university lecturers to give specialized talks and seminars, or sending their teachers to costly conferences and conventions once or twice per year. The return from the money put in this sector will continue to be "weak" if schools and school districts keep investing exclusively in these isolated PD activities (Odden, Archibald, Fermanich, \& Alix Gallagher, 2002).

As pointed out by Guskey (2002), "to be successful, professional development 
must be seen as a process, not an event" (p. 388) and it needs to provide teachers with "specific, concrete, and practical ideas that directly relate to the day-to-day operation of their classrooms" (p. 382). Large-scale survey studies conducted in the United States with teachers from different school subjects matters -especially mathematics and science- have identified a series of features related to the content and design of PD programs that teachers tend to value positively. Scholars have referred to these features as "features of high-quality PD" (e.g., Bautista, Cañadas, Brizuela, \& Schliemann, 2015; Borko, 2004; Darling-Hammond \& McLaughlin, 2011; Desimone, 2009; Garet et al., 2001). According to teachers' self-reported data, PD activities that present these features tend to have positive effects on their knowledge and instructional practices.

With regards to content, high-quality PD focuses on the specific subject matter that the teacher teaches in class (e.g., mathematics, science, history), thereby providing the teacher with deeper understanding of the subject matter itself (content knowledge), of pedagogical strategies to teach that specific content to students (pedagogical knowledge), and of how students think of and learn the content (knowledge of student thinking) (Carpenter, Fennema, Peterson, Chiang, \& Loef, 1989; Penuel, Fishman, Yamaguchi, \& Gallagher, 2007). High-quality PD is "tailored" to teachers depending on their prior knowledge and level of expertise, is coherent with and responsive to their needs and interests, and aligned with the curricular requirements and standards of schools, districts and nations. Finally, highquality PD is voluntary and features elements of autonomy and choice (Putnam \& Borko, 2000).

Regarding design features (structure and working dynamics), high-quality PD provides teachers with a) active learning opportunities, including activities to engage in exploration, reflection and discussion; b) contexts for collective participation and collegial sharing; c) constructive and non-prescriptive feedback; and d) sustained follow-up support after program completion (Bautista et al., 2015; Desimone, 2009; Sherin \& Han, 2004). Teachers need extended periods of time to process and reflect on the new ideas that are presented to them, try them out in class, and discuss them with their colleagues. Thus, scholars have concluded that PD that truly fosters teachers' learning and change needs to be intensive and sustained, instead of short and sporadic, involving significant numbers of contact hours over long periods of time. Activities with longer duration are said to provide greater opportunities for comprehensive analysis of subject content, pedagogies, and student thinking (Garet et al., 2001). Similarly, activities spread over time including more than 20 hours of contact time are generally more effective (Desimone, 2009).

\section{Rationale and Structure}

The title of the present monograph published by Psychology, Society and Education (PSE) is "Teacher Professional Development: International Perspectives and Approaches." The monograph advocates a situational, contextual, and ecological understanding of teacher PD. As pointed out by Opfer and Peder (2011), most literature on teacher PD has focused on individual activities or programs, looking at 
them in isolation from the complex and dynamic environments in which teachers live. In other words, researchers have been primarily concerned with the micro factors and contexts of PD (e.g., the effect of isolated activities), ignoring influences from the meso (institutional, school system) and the macro factors and contexts (cultural, societal, political, economic).

To fill this gap in the literature, this monograph brings together a series of articles that feature the perspectives and approaches to teacher PD of nations heavily committed to research and/or practice in this field. In our invitation letter to the authors, we explained that we were interested to learn about PD practices that had proven to be particularly successful, powerful, and/or beneficial for teachers in their respective countries. We encouraged the authors to offer general overviews of the PD models in place within their respective nations, and we clarified that articles did not have to be exclusively based on their own prior work and/or research. We offered the authors several guiding questions to articulate their papers, such as: What is currently working (or working "best") in teacher PD in your nation? What are the theoretical basis for those perspectives and approaches? What are the most important challenges for teacher PD in your nation today? In your view, what are some possible future venues for PD research and practice in your nation? What can other countries learn from the way/s in which your own nation is addressing teacher PD? The authors were given the freedom to tackle these questions or any others that they considered most pertinent or interesting.

We invited authors from five countries in which, according to the literature, highly effective and/or innovative PD initiatives have been designed and implemented over the past years. One of the contributions comes from the United States of America, surely the country that currently conducts the most cutting-edge research in the field of teacher PD. We also invited contributions from Australia, Hong Kong, Finland, and Singapore, some of the top-performers in education today based on indicators such as students' test scores in international comparisons, graduation rates, and percentage of students pursuing higher education -World Economic Forum's Global Competitiveness Report 2014-2015, see Schwab (2015). The literature has shown that these nations have indeed established strong systems to promote teacher learning, drawing on the tenets of effective professional learning outlined by educational research (Wei, Darling-Hammond, Andree, Richardson, \& Orphanos, 2009). PD is considered to be a high priority in these countries, and teachers are truly regarded as professionals (Darling-Hammond et al., 2010). Understanding more about how these nations are succeeding has the potential to inform PD policies and practices in other countries around the world. The monograph closes with a contribution from Spain, the country where Psychology, Society and Education is edited. The author discusses the five prior articles and reflects on how the ideas presented could improve the PD currently offered to Spanish teachers.

We turn now to introduce the articles included in the monograph, following the same order with which they are presented. 


\section{United States of America}

Laura M. Desimone and Michael S. Garet are the authors of "Best practices in teachers' professional development in the United States." This article provides the monograph with a general conceptual framework for effective PD. The authors begin by presenting the original framework of critical features of "high-quality PD" (Desimone, 2009), which suggests five key features that make PD successful: content focus, active learning, coherence, sustained duration, and collective participation. The authors continue by discussing the insights gained from recent U.S. research that has tested these five features, based on which they propose a refined version of the original framework. Desimone and Garet then examine the trends in how teacher PD has evolved in the U.S. recently, and conclude by discussing the challenges faced by schools and districts in implementing high-quality PD (Desimone \& Garet, 2015).

\section{Australia}

The title of the second contribution is "An Australian perspective on teacher professional development in supercomplex times." In this article, Lorraine M. Ling and Noella M. Mackenzie conceptualize teacher PD as a process involving multiple stakeholders and influenced by governments and other external bodies. The authors describe the kinds of PD initiatives currently offered to teachers in Australia, offering illustrative examples in different content areas and educational levels. In addition, the authors reflect on the kinds of PD opportunities that teachers may require in dealing with what they call an "era of supercomplexity," which is characterized by uncertainty, insecurity, and an unknown and unknowable future. Ling and Mackenzie present an interesting comparison between the existing PD opportunities in Australia and the opportunities that, in their view, would be most desirable in today's supercomplex times (Ling \& Mackenzie, 2015).

\section{Finland}

Hannele Niemi is the author of the third contribution, titled "Teacher professional development in Finland: Towards a more holistic approach." This article defines teacher PD as a continuum that spans the entire career of a teacher, including initial preparation programs. Niemi offers a comprehensive overview of the Finnish perspectives and approaches to PD. Teachers in Finland are seen as developers of themselves and the school community. Even during pre-service training, they are provided with opportunities to work in contexts that foster their autonomy and agency. Finnish teachers are equipped with competencies for research, which makes them capable of designing school-based research projects. In this article, Niemi describes four cases that illustrate how to support teacher PD through multiprofessional cooperation, promote pedagogical innovation through design-based approaches, connect pre-service and in-service research-based teacher education, and provide new teachers with support through induction periods (Niemi, 2015). 


\section{Hong Kong}

The fourth article, authored by Bick Har Lam (2015), is titled "Teacher professional development in Hong Kong compared to Anglo sphere: The role of Confucian philosophy". This article presents a thorough review of Hong Kong's teacher PD policies and practices over the past four decades, comparing them with the policies and practices currently adopted in Anglo-Saxon nations. Documentary analysis is used as the main research methodology. Lam shows that, similar to other countries, teacher PD in Hong Kong has gone thorough clearly distinctive phases, ranging from an approach purely focused on upgrading teachers' skills through training courses to a more sophisticated approach that conceives PD as lifelong learning. However, the author argues that the fact that Hong Kong is a Confucian heritage culture has introduced important differences in the ways teachers engage in PD. Based on a detailed discussion of these differences, Lan draws conclusions and implications intended to help other countries in improving their PD policies and practices.

\section{Singapore}

The title of the fifth contribution is "Teacher professional development in Singapore: Depicting the landscape," authored by Alfredo Bautista, Joanne Wong and Saravanan Gopinathan. This article provides a general description of the PD resources available to the teachers who work in the primary and secondary schools run by Singapore's Ministry of Education. There are multiple types of activities in which these teachers can engage during their 100 hours of yearly PD entitlement, ranging from formal/structured courses and programs to more informal/reform-type initiatives (action research, lesson study). Most PD is subject-specific and provides teachers with opportunities for network learning, collegial sharing, and collaboration. The authors argue that Singapore's comprehensive set of PD resources, considered as a whole, presents the features of high-quality PD described in the literature. However, they suggest that more research is needed to examine the extent to which such ambitious PD model is enhancing teachers' practices and students' learning (Bautista, Wong, \& Gopinathan, 2015).

\section{Spain}

The closing piece of the monograph is authored by Elena Martín, and titled "Pathways that converge in teacher professional development: Are they present in Spain?" This article accomplishes two goals. First, it elaborates on the five articles presented in the monograph, analyzing the common features of the teacher PD perspectives and approaches considered today as being most effective. Martín argues that the main axes of change revolve around teachers' career-long development, reflection in school-based communities of practice, and focus on students' voices. Moreover, she argues that teacher PD policies need to be coherent with more global policies aimed at enhancing the quality of education. Second, using the identified axes of teacher change as a framework, Martín discusses the situation of teacher PD in Spain. This analysis depicts a rather heartbreaking landscape, with important 
limitations with regards to both the specific PD activities offered to teachers and the underlying teacher PD model (Martín, 2015).

We invite the readers of Psychology, Society and Education to reflect about how the ideas presented in the different pieces of this monograph could be used to improve teacher PD theory, policy, and practice in their own countries.

\section{References}

Apple, M. W. (2001). Comparing neo-liberal projects and inequality in education. Comparative Education, 37(4), 409-423.

Avalos, B. (2011). Teacher professional development in teaching and teacher education over ten years. Teaching and Teacher Education, 27(1), 10-20.

Ball, D. L. (1995). Developing mathematics reform: What don't we know about teacher learning -- but would make good working hypotheses? Paper presented at the Conference on Teacher Enhancement in Mathematics K-6, Arlington, VA.

Barber, M., \& Mourshed, M. (2007). How the world's best-performing school systems come out on top. London: McKinsey and Company.

Bautista, A., Cañadas, M. C., Brizuela, M. B., \& Schliemann, A. D. (2015). Examining how teachers use graphs to teach mathematics in a professional development program. Journal of Education and Training Studies, 3(2), 91-106. http://redfame.com/journal/index.php/jets/article/view/676/624

Bautista, A., Tan, L. S., Ponnusamy, L. D., \& Yau, X. (2015). Curriculum integration in Arts Education: Connecting multiple Art forms through the notion of 'space'. Journal of Curriculum Studies. DOI: 10.1080/00220272.2015.1089940

Bautista, A., Wong, J., \& Gopinathan, S. (2015). Teacher professional development in Singapore: Depicting the landscape. Psychology, Society and Education, 7(3), 311326.

Borko, H. (2004). Professional development and teacher learning: Mapping the terrain. Educational Researcher, 33(8), 3-15.

Burnaford, G. E., Brown, S., Doherty, J., \& McLaughlin, H. J. (2007). Arts integration. Frameworks, research, and practice: A literature review. Washington, DC: Council of Chief State School Officers.

Carpenter, T. P., Fennema, E., Peterson, P. L., Chiang, C. P., \& Loef, M. (1989). Using knowledge of children's mathematics thinking in classroom teaching: An experimental study. American Educational Research Journal, 26, 499-531.

Darling-Hammond, L. (2010). Teaching for deeper learning: Developing a thinking pedagogy In A. P. C. Avila, C. Hui, J. H. Lin, J. C. Peng Tam, \& J. C. Lim (Eds.), Rethinking Educational Paradigms: Moving from Good to Great. CJ Koh Professorial Lecture Series No. 5 (pp. 13-18). Singapore: Office of Education Research, National Institute of Education.

Darling-Hammond, L., Chung Wei, R., \& Andree, A. (2010). How high-achieving countries develop great teachers. Stanford Center for Opportunity Policy in Education Research Brief, 1-8.

Darling-Hammond, L., Chung Wei, R., Andree, A., Richardson, N., \& Orphanos, S. (2009). Professional learning in the learning profession: A status report on teacher development in the United States and abroad. Standford University, CA: National Staff Development Council. 
Dede, C., Ketelhut, D. J., Whitehouse, P., Breit, L., \& McCloskey, E. M. (2009). A research agenda for online teacher professional development. Journal of Teacher Education, 60(1), 8-19.

Desimone, L. M. (2009). Improving impact studies of teachers' professional development: Toward better conceptualizations and measures. Educational Researcher, 38(3), 181199.

Desimone, L. M., \& Garet, M. S. (2015). Best Practices in Teachers' Professional Development in the United States. Psychology, Society and Education, 7(3), 252263.

Desimone, L. M., Porter, A. C., Garet, M. S., Yoon, K. S., \& Birman, B. F. (2002). Effects of professional development on teachers' instruction: Results from a three-year longitudinal study. Educational Evaluation and Policy Analysis, 24(2), 81-112.

Fullan, M. G., \& Miles, M. B. (1992). Getting reform right: What works and what doesn't. Phi Delta Kappan, 73, 745-752.

Garet, M. S., Cronen, S., Eaton, M., Kurki, A., Ludwig, M., Jones, W., . . Sztejnberg, L. (2008). The impact of two professional development interventions on early reading instruction and achievement (NCEE 2008-4030). Washington, DC: National Center for Education Evaluation and Regional Assistance, Institute of Education Sciences, U.S. Department of Education.

Garet, M. S., Porter, A. C., Desimone, L., Birman, B. F., \& Kwang, S. Y. (2001). What makes professional development effective? Results from a national sample of teachers. American Educational Research Journal, 38, 915-945.

Garet, M. S., Wayne, A. J., Stancavage, F., Taylor, J., Eaton, M., Walters, K., \& Doolittle, F. (2011). Middle school mathematics professional development impact study: Findings after the second year of implementation. (NCEE 2011-4025). Washington, DC: National Center for Education Evaluation and Regional Assistance, Institute of Education Sciences, U.S. Department of Education.

Gersten, R., Dimino, J., Jayanthi, M., Kim, J. S., \& Santoro, L. E. (2010). Teacher study group: Impact of the professional development model on reading instruction and student outcomes in first grade classrooms. American Educational Research Journal, 47, 694-739.

Guskey, T. R. (2002). Professional development and teacher change. Teachers and Teaching: theory and practice, 8(3/4), 381-389.

Hill, H. C., Beisiegel, M., \& Jacob, R. (2013). Professional development research: Consensus, crossroads, and challenges. Educational Researcher, 42(9), 476-487.

Kaur, B. (2012). Equity and social justice in teaching and teacher education. Teaching \& Teacher Education, 28, 485-492.

Kazemi, E., \& Hubbard, A. (2008). New directions for the design and study of professional development: Attending to the coevolution of teachers' participation across contexts. Journal of Teacher Education, 59(5), 428-441.

Knight, P. (2002). A systemic approach to professional development: learning as practice. Teaching and Teacher Education, 18(3), 229-241.

Lam, B. H. (2015). Teacher Professional Development in Hong Kong Compared to Anglosphere: the Role of Confucian Philosophy. Psychology, Society and Education, $7(3), 295-310$. 
Ling, L. M., \& Mackenzie, N. M. (2015). An Australian perspective on teacher professional development in supercomplex times. Psychology, Society and Education, 7(3), XXXX.

Little, J. W. (1993). Teachers' professional development in a climate of educational reform. Educational Evaluation and Policy Analysis, 15(2), 129-151.

Martín, E. (2015). Pathways that converge in teacher professional development: Are they present in Spain? Psychology, Society and Education, 7(3), 327-342.

Niemi, H. (2015). Teacher professional development in Finland: Towards a more holistic approach. Psychology, Society and Education, 7(3), 279-294.

O’Dwyer, L. M., Master, J., Dash, S., De Kramer, R. M., Humez, A., \& Russell, M. (2010). E-learning for educators: Effects of on-line professional development on teachers and their students: Findings from four randomized trials: Retrieved from http://www.bc.edu/research/intasc/PDF/EFE_Findings2010_Report.pdf.

Odden, A., Archibald, S., Fermanich, M., \& Alix Gallagher, H. (2002). A cost framework for professional development. Journal of Education Finance, 28(1), 51-74.

Opfer, V. D., \& Peder, D. (2011). Conceptualizing teacher professional learning. Review of Educational Research, 81(3), 376-407.

Penuel, W. R., Fishman, B. J., Yamaguchi, R., \& Gallagher, L. P. (2007). What makes professional development effective? Strategies that foster curriculum implementation. American Educational Research, 44, 921-958.

Powell, D. R., Diamond, K. E., Burchinal, M. R., \& Koehler, M. J. (2010). Effects of an early literacy professional development intervention on head start teachers and children. Journal of Educational Psychology, 102(2), 299-312. doi:10.1037/a0017763

Putnam, R. T., \& Borko, H. (2000). What do new views of knowledge and thinking have to say about research on teacher learning? Educational Researcher, 29(1), 4-15.

Schwab, K. (2015). World Economic Forum's Global Competitiveness Report, 2014-2015. Retrived from: http://reports.weforum.org/global-competitiveness-report-20142015/. Switzerland: World Economic Forum.

Sherin, M. G., \& Han, S. Y. (2004). Teacher learning in the context of a video club. Teaching and Teacher Education, 20, 163-183.

Tan, C. Y., \& Dimmock, C. (2014). How a 'top-performing'Asian school system formulates and implements policy: the case of Singapore. Educational Management Administration \& Leadership, 1741143213510507.

Todd, R., J. (2010). Curriculum integration. Learning in a chanching world. Victoria, AU: McPerson's Printing Group.

Wei, R. C., Darling-Hammond, L., Andree, A., Richardson, N., \& Orphanos, S. (2009). Professional learning in the learning profession: A status report on teacher development in the United States and abroad. Dallas, TX: National Staff Development Council. Downloaded from: http://edpolicy.stanford.edu.

Yoon, K. S., Duncan, T., Lee, S. W. Y., Scarloss, B., \& Shapley, K. L. (2007). Reviewing the evidence on how teacher professional development affects student achievement. Washington, DC: National Center for Educational Evaluation and Regional Assistance, Institute of Education Sciences, U.S. Department of Education. 